\title{
"The Effects of Using Reader's Theatre-Based Instruction on Improving EFL Oral Reading Fluency, Reading Comprehension and Reading Speed Skills among Preparatory Stage Pupils"
}

\section{Dr. Hasnaa Sabry Abdel-Hamid Ahmed Helwa}

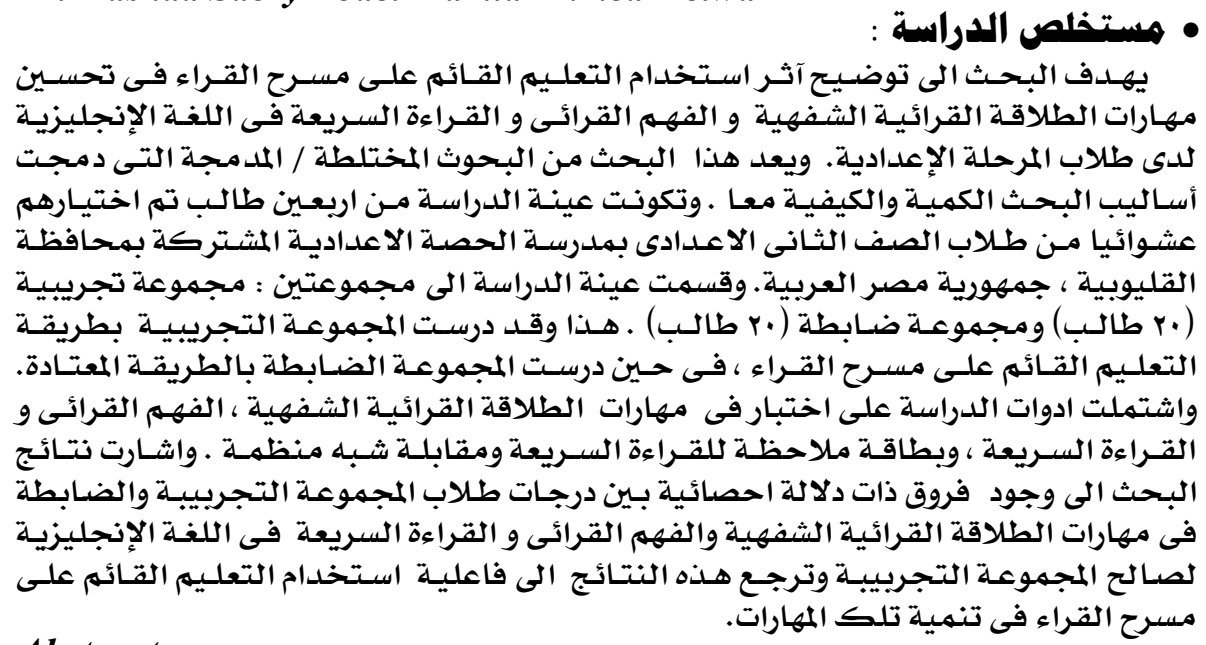

\section{Abstract}

The aim of this research is to investigate the effects of using readers' theatre based instruction on improving EFL oral reading fluency, reading comprehension and reading speed skills among preparatory stage pupils. The design of the research is a mixed research methodology. It combines both quantitative and qualitative modes of inquiry. The researcher used two groups: an experimental group and a control group.Both groups were tested before and after the intervention. Subjects of the present research consisted of forty pupils who were chosen randomly from second year pupils enrolled in El-Hesa preparatory school for girls and boys, Qalubia governorate, Egypt. They were divided into two groups: an experimental group $(N=20)$ pupils who were taught through reader's theatre based instruction and a control group $(N=20)$ pupils who were taught in the regular way. The instruments of the research included an EFL oral reading fluency test, reading comprehension test, reading speed test, an observation checklist for reading speed, and a semi-structured interview. Results of the research revealed a statistically significant difference between the mean score of the experimental group and that of the control group in the post test of EFL oral reading fluency, reading comprehension and reading speed skills in favor of the experimental group. These results were ascribed to using readers' theatre- based instruction.

Kevwords:Readers' Theatre- Based Instruction-EFL Oral Reading Fluency Skills-EFL Reading Comprehension Skills-EFL Reading Speed Skills.

\section{1}




\section{- Introduction:}

Reading is a purposeful, complex, cognitive and an interactive process that requires the reader to bring experiences and explanations to the text while processing what the text offers. It is a process of making meaning from text and requires two important tasks. The first task the student must perform is to recognize the printed words (i.e., decode).The second task is that the student must be able to construct meaning from the words that were decoded (i.e.,comprehend) .The purpose of reading is to assemble meaning from a text. Even though fluency has been a neglected factor in reading, it is an important contributor to comprehension skills. Fluency is an important domain of the reading process that aims at gaining meaning from the text .To accomplish this, a reader needs to recognize the text and read it fluently and accurately to identify, recognize, and read words automatically with expression (Cox, Miller \& Berg, 2012, Derringer, 2013, Moore, 2011, Morra,2006, Samuels, 2006, Visser,2013).

When readers are able to read with fluency and comprehension, they are considered proficient. Thus, there is a correlation between fluency and comprehension. Fluency is a reading skill that is considered the bridge between decoding and comprehension, so students should develop this important link in the reading process (Rasinski, 2004). As a result, Rasinski (2013) conducted reading instruction model that starts with accurate word knowledge (phonics, spelling, vocabulary), fluency (automaticity in word recognition, decoding and meaning prosody) and comprehension.

The early elementary years are the most critical in developing and mastering those reading skills. In order to improve reading comprehension, a reader must first decode the words. Building fluency is the key to reading comprehension. Oral Reading fluency $(O R F)$, the ability to read accurately at an appropriate rate and with meaningful expression and phrasing, has been shown to be associated with reading comprehension for students through the intermediate grades. Additionally, ORF has been shown to

\section{2}

Journal of Arabic Studies in Education \& Psychology (ASEP) 
be a better predictor of reading comprehension than other reading assessment measures such as direct questioning or retelling (Rasinski, 2004).

The National Reading Panel (2000) identified fluency as one of the five major components of reading that teachers must include in their instruction. According to the National Reading Panel, fluency is reading text with speed, accuracy, and expression. It is the ability to read words accurately and quickly and depends upon the type of reading, the reader's familiarity with the words, and the amount of practice reading text. The definition of fluency is extended to include the ability to comprehend the material being read. The components of fluency are automaticity, prosody, accuracy and speed, expression, intonation and phrasing. Speed refers to the number of words a person correctly reads per minute (WCPM). Accuracy refers to reading the material with few errors. Expression refers to the ability of the reader to use correct phrasing, tone, and pitch while reading text aloud. Comprehension refers to the ability to understand the text being read. Automaticity refers to accurate, quick word recognition, not to reading with expression. Although students may recognize words, their oral reading may be expressionless and/or lack phrasing and punctuation. Fluent readers know when to pause within and at the ends of sentences and when to change emphasis and tone.

Fluency is the ability to read a text accurately, smoothly, quickly, and with expression. There are two types of fluency; oral and silent reading fluency. Silent reading tends to be a better method of assessing reading comprehension, while oral reading provides important information about the reader's proficiency in applying reading strategies. Fluency develops over time with practice. It is the accurate and rapid naming or reading of letters, sounds, words, sentences, or passages. When students can perform reading and reading-related tasks quickly and accurately, they are on the path to fluency, an essential element of comprehension and mature reading. To become fluent, students need to learn to decode words rapidly and accurately, in isolation

\section{3}


as well as in connected text, and to increase reading speed while maintaining accuracy.Therefore, teachers need to provide students with opportunities for repeated oral reading that includes support and feedback from teachers and peers, determine students' reading levels, and ensure that texts are matched to them and apply systematic practices in classrooms to instruct and monitor student progress (Tankersley, 2003, Vaughnm and Thompson, 2004)

$O R F$ is the ability to read text accurately and quickly. It is reading in which words are recognized automatically. When fluent readers read, they group words quickly to help them gain meaning from what they read. Their oral reading sounds natural and their silent reading is smooth and unenumbered by an over emphasis on word-by-word analysis. According to Rasinski (2003b), using accuracy and automaticity together provides a measure of $O R F$. Specifically, accuracy is determined by the percentage of words read correctly and represents a valid measure of reading proficiency. Automaticity examines the number of words read correctly in a fixed interval of time, generally one minute, and provides an estimate of an individual's reading rate. In addition to accuracy and automaticity, the prosodic features of oral reading must also be considered. Prosody is the feature of oral reading that addresses tonal quality, pace, and the rhythmic aspects of language that should be present when reading. It is also a compilation of spoken language features that includes stress or emphasis, pitch variations, intonation, reading rate, and pausing.

Mendes (2012) defined $O R F$ as the ability to read connected text with speed and accuracy. It contains three main parts: automaticity, rate, and prosody (phrasing and expression). Also, Rasinski (2002) indicated that ORF is a critical factor necessary for reading comprehension. He referred to the study conducted by the National Assessment of Educational Progress (NAEP) that found a close relationship between fluency and comprehension. Thus, fluent readers do not focus on decoding words. They can recognize words and construct meaning at the same time. Additionally, they are able to make connections between the

\section{4}


text and their background knowledge. They are more likely to comprehend and remember the material they read.

Reading comprehension is the active process of constructing meaning from text. It involves accessing previous knowledge, understanding vocabulary and concepts , making inferences, and linking key ideas. It cannot be learned through rote instruction, but requires a series of strategies that influence understanding of text.Vaughnm and Thompson (2004) clarified that reading comprehension includes applying one's knowledge and experiences to the text, setting goals for reading, and ensuring that they are aligned with the text; using strategies and skills to construct meaning during and after reading; adapting strategies that match the reader's text and goals, recognizing the author's purpose; distinguishing between facts and opinions, and drawing logical conclusions.

Therefore, the relationship between ORF and comprehension is reciprocal. That is, ORF leads to better comprehension because meaningful phrases facilitate the comprehension of the larger units of a sentence, passage, and story. Also, better understanding of the text allows a student to read more quickly and accurately. Fluency is important to all students because it bridges the gap between just word recognition and comprehension. Fluent readers focus their time and attention on comprehension tasks and making connections among the ideas in the text and their background knowledge, while non-fluent readers spend much of their time and attention fixated on decoding individual words (Osborn, 2007).

Reading speed is the measure of how many words students read in a given time period. It is how quickly a student reads a particular reading passage at his level in a given time. It is important but should not be the primary goal of reading fluently. Although rate may be a measure of word recognition automaticity, it does not capture the prosodic component of reading, that component connects comprehension or the making of meaning to fluency. For students to read with appropriate expression, they need to be aware of the meaning of passage. Thus, it does not

\section{5}

Journal of Arabic Studies in Fducation \& Psychology (ASEP) 
provide the complete picture of reading fluency. A student who only reads words quickly but does not use expression or understand the words he is reading is lacking a major part of the equation. Likewise a pupil who reads each word accurately but lacks expression in his reading is not really paying attention to the cues of the language of the text. This is not reading fluently. Fluency must include all components of rate, accuracy and prosody (Rasinski, Rickli \& Johnson, 2009).

The importance of reading speed to successful reading is neatly portrayed in the two contrasting circles of weak and good reader. In the virtuous circle of the good reader, reading faster is linked to greater quantity of reading, better understanding, and greater enjoyment, whereas in the vicious circle of the weak reader lack of understanding, lack of enjoyment, lack of reading, and slow reading feed off each other. It is the teacher's role, therefore, to help learners move from this cycle of frustration and enter instead the cycle of growth that the virtuous circle represents. Therefore, reading speed is described as the ability to produce and process the target language with native speaker-like ease (Macalister, 2010, Madden ,2009).

Problems in fluency may cause difficulties with comprehension, which is the goal of reading. ORF is a bridge between the two major components of reading: word decoding and comprehension. Students lacking fluency are concerned with decoding and word recognition and are less likely to be able to construct meaning from what they are reading. Poor readers tend to spend less time on reading than fluent readers. They may avoid reading which may lead to the loss of skills and cause them to lag further behind other students at their grade level. If students do not develop fluent reading in the early grades, it can impact their reading speed, accuracy, comprehension and enjoyment of printed text. They are reluctant to read aloud or read to others as their reading is slow and tedious to listen to. Inefficient readers are often not engaged during reading instruction because they become frustrated with the text. When students are unable to read fluently, it can result

\section{6}


in poor comprehension, an essential component of reading success (Rasinski, 2003a, Ruskey, 2011).

Thus, teaching ORF is an important part of the reading curriculum at earlier age, but it is often neglected in reading instruction programs. Teachers want students to read smoothly and fluently but do not have a true understanding of how to reach that goal. A common misconception is that teaching ORF is only important when students are young and show large gaps in learning. For most teachers, implementing explicit fluency instruction is a time-consuming process consisting of repeated readings, running records, informal reading inventories, and timed oral fluency passages (Wolf and Katzir-Cohen ,2001)

The lack of ORF in poor readers is evidenced by their slow, faltering, and inconsistent rate, poor phrasing, and inadequate intonation patterns. When readers are proficient, they read fluently with adequate speed, and when they read aloud, they use appropriate phrasing, intonation, and their oral reading is a reflection of their spoken language. Students who manifest difficulties in reading often experience difficulties in ORF as well. Fluent readers use expression and adjust their pace appropriately. They read effortlessly and interpret meaning through the use of good phrasing, and appropriate voice tone. Fluent readers group words together in phrases that convey meaning and consistent with punctuation, and correspond to sentence structure. They understand what they read and make links with prior knowledge as well as recognize the purpose for reading. They enjoy reading aloud as well as reading to others as they have experienced success in their reading experiences (Callard, 2008).

Barriers to improvements in reading speed can be related to teaching activities and tasks such as a lack of vocabulary, lack of knowledge that relates to the strategy of studying new vocabulary, and the inability to use context signals. Additionally, a lack of training in how to teach good reading habits can result in students who read with the purpose of memorization without getting details, a fear of misunderstanding leading to excessive scrutinizing while

\section{7}

Journal of Arabic Studies in Education \& Psychology (ASEP) 
reading and reading word by word instead of scanning. It may be related to the physiological characteristics of the reader including weaknesses in intelligence, poor vision, and a lack of linguistic knowledge, as well as movements that happen unnecessarily while reading like nodding, whispering and humming (Alarfaj and Alshumaimeri, 2012, Madden,2009).In addition, Kuhn and Stahl (2003) clarified that there are a number of physical factors that could improve reading speed such as: a comfortable atmosphere with the book and arms being placed on the desk while reading, moving the eyes only instead of the head; focusing on the skills of rapid reading; familiarizing students with finger tracking of the written lines to avoid distraction; providing coherent texts that do not contain difficult expressions and stimulating speed reading at an early stage of education

Thus, improving students' ORF, reading speed and comprehension is a major challenge faced in many classrooms. ORF has been identified as a key goal for the elementary school reading curriculum as research links the reciprocal relationship between fluency and comprehension Fluency facilitates comprehension through many aspects, for instance, word recognition, phrasing, and prosody, and good fluency in reading lead to a better academic efficacy to students. Thus, it is very important for an EFL teacher to find an easy and efficient method to develop students' ORF, reading comprehension and reading speed skills. Despite the academic importance of $O R F$, reading comprehension and speed, many teachers are not familiar with effective methods of instruction for improving fluency and ways for integrating reading fluency within the reading classroom curriculum.

Although repeated reading is an effective approach toward teaching fluency, students often find it boring and monotonous. Teachers may also lack motivation to carry out the process of fluency instruction because of time constraints. A more desirable solution for fluency instruction may be readers' theatre (RT), where students are given a script and a specific part, as if they were in a play. In RT,

\section{8}


character interpretation is unique to the reader. During the process of decoding a script, students must analyze the story and the characters to determine how a line will be read. Therefore, in RT, fluency is dependent on the meaning discovered by the reader. Students create the drama through their voices as they expressively read their parts instead of acting and using props. The students are given the script several days in advance and are provided with time to read and reread their assigned parts prior to a final performance (Martinez, Roser, \& Strecker, 1998, Visser,2013).

Rereading and practicing the text four or five times is usually sufficient for most students. After the rehearsal period, the student reads the passage back to the coach, who offers feedback and encouragement. The student should be reading short passages or stories, poems, plays or specific paragraphs that are appropriate for his or her development, background, and independent reading level. Repeating a passage over and over again can give the reader confidence, speed, and a solid understanding of the meaning of what is being read. Having the coach to listen to the student allows for immediate guidance and feedback to improve the performance. Feedback that is direct and immediate helps the student improve and perfect the delivery and fluency level of the material (Tankersley, 2003).

Therefore, one of the most effective ways teachers can promote fluency development particularly for beginning readers is through the use of RT. It offers positive models of fluent reading as demonstrated by a teacher or other accomplished readers, and provides beginning readers with a legitimate reason for rereading text in an enjoyable and engaging format. It is a way to interpret literature without the constraints of skills, rote memorization, or assignments. English language learners in elementary school struggle with reading fluency and pronunciation skills. In fact, some of these students have low self-esteem, because they are not comfortable in the classroom and may have some negative attitudes towards mispronunciations. With RT, students were assigned a character according to their reading level

\section{9}

Journal of Arabic Studies in Fducation \& Psychology (ASEP) 
and they were able to practice and repeat the same character lines until they were familiar with the execution of the phrase (Fredericks, 2007a-b, Morales, 2013).

In addition, $R T$, as a dramatic approach to reading, opens up a construction and reconstruction of literature that allows students to comprehend text in a creative and meaningful way. It provides students with opportunities to synthesize texts and make character analysis through a type of role-play. It encourages social interaction with peers as students work in small groups to practice scripts. During $R T$, students read from a practiced script. They do not memorize their lines, nor are stage sets or props used. They make the story come alive with expressive reading known as prosody. In practicing their lines, they do a great deal of rereading. Repeated reading, as a strategy, has been proven to improve both fluency and comprehension. Therefore, when RT is used correctly, it is naturally fun and feels like play. When children engage in an educational play activity, they are more likely to relax and learn. In a stress free classroom, they begin to use language in operation, and express themselves as competent English speakers (Smith, 2011).

$R T$ has been shown to be effective in helping students gain ORF, comprehension skills and reading speed. It sets a purpose for reading, rereading, and analyzing text to create understanding. Students must extend literal interpretation of the text to explore deeper meaning. Scripts become part of their imagination as readers offer an expressive voice to their character and a personalized interpretation of the text through dramatic play. They are able to better comprehend because of the personal connections made with text. They also make strong connections with the story and the characters because readers imagine themselves in the role of the character (Visser, 2013).

\section{- Context of the Problem}

Preparatory school pupils encounter difficulties in ORF where strategies concentrating on timed fluency and the recognition of sight words are ineffective if students are not given the opportunity to explore the meaning of the words in

\section{0}


the text. Lack of comprehension instruction at the preparatory level has led students to decode but had a difficult time making connections with text. As they practice their fluency, it is important for teachers to listen for their use of expression and phrasing. These skills show that the reader is making meaning out of what s/he is reading. Most of the preparatory stage pupils are not fluent when they read aloud. Their readings are full of hesitations and repetitions. They make false starts and mistakes in pronunciation. In addition, they lack the ability to comprehend what they read. Thus, they need reading strategies allowing them to explore the meaning of the literature they read. The correct answer of the students centered all on the comprehension questions that are at the literal level (El-Garawany, 2010, Helwa, 2010a-b).

In the same context, Seifeddin (1991) clarified that teachers focus on word recognition, vocabulary development, grammar and comprehension because these are the goals of the most reading programs. Oral reading is practiced in the traditional manner where every student reads a sentence or a paragraph in turn while others listen to English being badly pronounced with poor stress and intonation. Therefore, students who struggle with fluency also struggle with text comprehension; they focus so much on decoding words that they pay less attention to understanding what they read. Similar to ORF problems, there can be multiple causes for reading comprehension difficulties, such as limited vocabulary knowledge or background information, restricted memory, difficulty with higher-order reasoning skills, linguistic abilities, difficulty with self-monitoring, or trouble understanding text structure.

Fluency instruction may be the missing element in reading instruction for most teachers, because most of teachers learned to teach reading with a focus on accuracy and comprehension. Few teachers were taught how to teach students to read quickly and automatically. However, they have learned that fluency is an essential element that bridges the gap between word recognition and 
comprehension. Though some students will learn to read accurately, quickly, and with prosody (good expression) with little direct instruction from teachers, many will require practice and support from peers and teachers to improve their fluency and make reading a more valued activity (Vaughnm and Thompson,2004) .

To document the problem of the study, a pilot study was conducted to find out the problem of ORF, reading comprehension and reading speed skills among second year students at El-Hessa preparatory school for boys and girls, Tukh, Qalubia Governorate, Egypt. It consisted of three parts. The first part was an EFL ORF test. The results of the ORF test indicated that pupils are not able to read words correctly, quickly and with expression. They read the text dysfluently, making word recognition errors, laboring in their reading and reading without appropriate expression. The second part was an EFL reading comprehension test. The results indicated the weakness of reading comprehension skills among the preparatory stage pupils. They focused only on the questions whose answers are found in the passage. They did not know the meaning of some vocabulary; therefore they left the answer blank. Thus, the correct answer of the students centered all on the comprehension questions at the literal level. The third part was an EFL reading speed test. The results of the reading speed indicated that there is a lack of reading speed skills among the pupils. They read very slowly and fixed their eyes on one direction while reading. They do not control eye's movement while reading the text and do not vary their reading rates.

\section{- Statement of the Problem}

In spite the importance of EFL ORF, reading comprehension and reading speed skills, second year preparatory stage pupils have difficulties in understanding reading passages. They lack ORF and are slow readers. The present research aims at examining the effect of readers' theatre - based instruction on improving EFL ORF, reading comprehension and reading speed skills among preparatory stage pupils.

\section{2}


- Questions of the Study

- What are the features of a program based on Reader's Theatre Based Instruction for improving EFL oral reading fluency, reading comprehension and reading speed skills among preparatory stage pupils?

- How far is Reader's Theatre Based-Instruction effective in improving EFL oral reading fluency among preparatory stage pupils?

- How far is Reader's Theatre-Based Instruction effective in improving EFL reading comprehension skills among preparatory stage pupils?

- How far is Reader's Theatre -Based Instruction effective in improving EFL reading speed skills among preparatory stage pupils?

\section{- Review of Related Studies}

$R T$ improves the ability to read connected text rapidly, smoothly, effortlessly, and automatically with little conscious attention to the mechanics of reading. It is an instructional practice that develops fluency and involves students in the oral reading of a text. In the case of $R T$, students repeatedly practice reading a script with an authentic reason for rereading. Successful readers master reading fluency which includes accuracy, automaticity, and prosody. Thus, it is an excellent strategy for developing fluency for all types of learners. Pupils characterized by the ability to read quickly and accurately will be able to read with accuracy, automaticity, and prosody that ultimately lead to better comprehension of the text (Tharp, 2012).

\section{- A number of studies have investigated the variables of} this study as follows:-

Millin and Rinehart (1998) compared an experimental group of 14 students with a control group of 14 students. The quantitative research was based on pre-and post-test scores of variables such as oral reading comprehension and oral reading rate. The qualitative research was based on interviews with students. The quantitative analysis showed that $R T$ enhanced oral reading word recognition and comprehension of words. Those with the highest gains were those who had the lowest pre-test scores. Oral reading

\section{3}


ability improved in successive texts and students transferred skills to new texts they read. There was also a definite change in attitude towards reading. The students became far more enthusiastic about reading; they put more effort into reading other material, read more books and enjoyed silent sustained reading more than previously. They also displayed more positive attitudes to reading aloud. The findings demonstrated that $R T$ activities may offer struggling readers an opportunity to read aloud with enhanced skill, including more accurate word recognition, better expression, and improved fluency.

Martinez, Roser and Strecker (1998) investigated the influence of $R T$ on the reading fluency of second graders. They found out that a group of second grade students doing repeated readings through $R T$ made twice the gains in reading rate than a control group and also improved reading comprehension and expressiveness. The children's reading speed increased by an average of 17 words a minute for the second graders. The students were eager to practice because they knew they would perform later.

Carrick (2000) examined the effects of RT as a teaching strategy on improving oral reading rate, oral reading word accuracy, and reading comprehension. The sample consisted of 179 fifth grade students from four different schools. A total of 47 students formed the control group (traditional method), 76 students formed the quasi-control group (paired repeated reading), and 56 students formed the experimental group (Readers Theatre). Readers Theatre, paired repeated reading, and the traditional method of using basal reading textbook were examined to determine their effectiveness in improving reading rate, reading word accuracy, and reading comprehension. Reading rate was calculated by multiplying number of words in the passage by 60 and divided by the number of seconds it took to read the passage. Reading accuracy was calculated by subtracting the number of miscues from the number of words in the passage. The results suggest that Readers Theatre does improve fluency, particularly oral reading rate and word accuracy and reading 
comprehension skills. The results of this study are consistent with Keen's (2003) that clarified the effect of instruction and practice through $R T$ on young readers' $O R F$. Keehn compares the difference in treatment implemented in two ways as an instructional intervention to promote $O R F$ in second grade classrooms. He also argues for $R T$ as a viable vehicle for $O R F$. The repeated readings with the RT format also helped second graders develop word recognition and comprehension. The children even averaged a 30 word per minute increase in rate.

Chen (2006) investigated the influences of $R T$ instruction on oral reading fluency, motivation for reading and students' perceptions of this oral reading instruction in an elementary English class. Participants in this study were 34 elementary students in Taiwan. They experienced RT instruction in English classes 4 times a week for a total of 5 weeks. Data were collected by oral reading tests and questionnaires before and after the instruction; and by the use of an informal interview with students after the instruction.The results indicated that most participants improved their ORF in terms of accuracy and speed after the instruction. Furthermore, they developed a greater motivation for reading in terms of intrinsic motivation and the social aspects of motivation in reading domain. Interview results also showed that $R T$ has gained recognition from most participants.

Dixon (2007) investigated the effect $R T$ via expository text on reading fluency and reading comprehension achievement of fourth-grade elementary students. The study consisted of a pretest-posttest control group design to test the hypotheses. The results of the study confirmed the strong correlation between reading fluency and reading comprehension. A reader's level of fluency changes with the level of difficulty of the material and the reader's level of background knowledge in the content that the text is about. The pretest and posttest results in this study suggested that students' reading fluency and comprehension were affected although not in a statistically significant way. 
Callard (2008) conducted a study using RT to increase third graders' reading fluency, comprehension, and motivation. The data was collected from DIBELS oral reading fluency scores, STAR reading comprehension scores, and results from a Reading Motivation Survey administered to all third grade students at the school and used as the baseline. The experimental and control groups consisted of 10 students and the RT intervention was conducted for 10 weeks. Data was collected and analyzed after the inclusion of $R T$ intervention. The results of the study confirmed the effectiveness of using $R T$ to increase third graders' reading fluency, comprehension, and motivation.

Jagger (2008) confirmed the effect of $R T$ on improving reading fluency and comprehension through using a quasiexperimental, nonequivalent control group design. The sample consisted of 4 fifth-grade classrooms, 2 classrooms participated in RT for 8 weeks, and 2 classrooms were the control. Pre and post-assessments measured students' fluency (i.e., reading rate and accuracy) and comprehension. The results clarified that there was significantly greater gains by the treatment group in reading fluency, reading rate and comprehension. Therefore, $R T$ is an effective teaching method in improving reading fluency and comprehension skills.

Moore (2011) confirmed the effectiveness of $R T$ in developing reading comprehension skills through conducting a study that focused on improving the reading comprehension of second grade struggling readers through the instructional activity of RT. In this study, Readers' Theater was researched and implemented to improve the reading comprehension in second grade struggling readers. Readers' Theater is a strategy that uses scripts that take the place of a text. Each student is given an assignment to read certain parts of the script. The students practice their lines several times independently, and then collectively as a group. After practicing as a group, the students perform the story they were reading. The students can perform for each other or other students in the school. Comprehension is

\section{6}


known to be enhanced using this strategy, because of the amount of times the students repeat the scripts. Three methods of data were used to determine if Readers' Theater was a successful strategy to improve reading comprehension. These methods were an observational checklist, comprehension quizzes, and a student survey. Results revealed that the students enjoyed using the scripts and were motivated to read them. Thus, Readers' Theater may have also been one factor that enabled student comprehension of these scripts.

In addition, Morris (2011) examined the effects of RT on second grade student's ORF and prosody, reading comprehension, and student's attitudes towards reading. Her study was a repeated measure design consisting of three four-week units with RT implemented as treatment in the second of the three units. The study was carried out in one second grade classroom over the course of 12 weeks. Data was collected in the form of pre-and post-assessments for each of the three units. The results of the study indicated that $R T$ helped maintain and improve oral reading rates and prosody for second grade students.

In their study, Kariuki and Rhymer (2012) investigated the effects of readers' theatre-based and tradition-based instruction on sixth-grade students' comprehension at a selected middle school. A sample of 10 students from sixth grade was randomly selected for each of the experimental and control groups. The results indicated there were significantly higher comprehension scores for the students in the experimental group. The results also suggested that the use of readers' theatre-based instruction increased the comprehension scores of students.

Owens (2012) studied the positive impact of $R T$ on student reading achievement as evidenced by students' scores on tests of reading fluency, comprehension, and motivation. Twenty-four second-grade students participated in the study. Data were collected in the form of pre-and post-assessments, rubrics, evaluations, and observation notes. Findings indicated that RT increased students' reading fluency, comprehension, and motivation. 
Dalton (2013) concluded that using repeated readings of $R T$ scripts had an impact on first grade students' fluency ability. His study hypothesized that using repeated readings of $R T$ scripts will improve students reading rate (words per minute) and their ability to read fluently. He indicated that modeling is also an effective method for improving fluency while reading. The student can listen to fluent reading and apply what they heard while they read orally. RT provides opportunities for modeling when students read aloud in a group and are able to model fluent reading for each other. Then, high achieving students can assist lower achieving students by modeling how to read aloud fluently. During modeling students participate in listening while reading silently. In this method, students follow along and read the text as it is being read aloud to them.

Visser (2013) described the effects of using RT as a strategy for improving the reading fluency, comprehension, and motivation of elementary English language learning (ELL) students. Results indicated RT is a motivational and effective strategy in teaching elementary ELL students to read in a second language. Recommendations for improving the effectiveness of using RT as a strategy include coping with performance anxiety, increasing the quantity of fluency practice, and incorporating $R T$ into different content areas.

\section{- Hypotheses of the Study}

Based on the related studies and research questions the following hypotheses were formulated:

- There is a statistically significant difference between the mean score of the experimental group and that of the control group in the post test of EFL overall oral reading fluency skills in favor of the experimental group.

- There is a statistically significant difference between the mean score of the experimental group and that of the control group in the post test of EFL oral reading fluency sub-skills in favor of the experimental group.

- There is a statistically significant difference between the mean score of the experimental group and that of the control group in the post test of EFL overall reading comprehension skills in favor of the experimental group.

\section{8}


- There is a statistically significant difference between the mean score of the experimental group and that of the control group in the post test of EFL reading comprehension sub-skills in favor of the experimental group.

- There is a statistically significant difference between the mean score of the experimental group and that of the control group in the post test of EFL overall reading speed skills in favor of the experimental group.

- There is a statistically significant difference between the mean score of the experimental group and that of the control group in the post test of EFL reading speed subskills in favor of the experimental group.

- Methodologv

- A. Participants

Subjects of the present research consisted of forty pupils $(N=40)$. They were chosen randomly from second year pupils enrolled in El-Hesa preparatory school for girls and boys, Qalubia governorate, Egypt. They were divided into two groups: an experimental group $(N=20)$ pupils who were taught through reader's theatre based instruction and a control group $(N=20)$ pupils who were taught in the regular way. To make sure that both groups were equivalent in the EFL oral reading fluency, reading comprehension and reading speed skills, the EFL oral reading fluency, reading comprehension and reading speed tests were administered to the control group and the experimental group before implementing the program. Mean, standard deviation and " $t$ " value of the two groups were computed.

Table (1):" $t$ " test between the control group and the experimental group in the pre-test of the overall EFL oral reading fluency skills

\begin{tabular}{|c|c|c|c|c|r|c|c|}
\hline Test & Group & N & Mean & S.D & T-Value & D.F & Sig. \\
\hline $\begin{array}{c}\text { EFL Oral Reading } \\
\text { Fluency Skills }\end{array}$ & Cont. & r. & 101.90 & 7.17 & 0.144 & 38 & \multirow{2}{*}{ N.S. } \\
\cline { 2 - 5 } & Exp. & r. & 101.55 & 8.15 & & & \\
\hline
\end{tabular}

Table (1) indicates that there is no significant difference between the mean scores of the two groups on the overall EFL oral reading fluency pre-test, where " $t$ " value is (0.144), which is not significant at (0.01) level of significance. This means that the two groups are equivalent in their EFL oral reading fluency skills.

\section{9}

Journal of Arabic Studies in Education \& Psychology (ASEP) 
Table (2): " $t$ " test between the control group and the experimental group in the pre-test of the overall EFL reading comprehension skills

\begin{tabular}{|c|c|c|c|c|c|c|c|}
\hline Test & Group & $\mathrm{N}$ & Mean & S.D & T-Value & D.F & Sig. \\
\hline $\begin{array}{c}\text { EFL Reading } \\
\text { Comprehension } \\
\text { Skills }\end{array}$ & Cont. & r. & 4.70 & 1.302 & & & \\
\cline { 2 - 5 } & Exp. & r. & 5.30 & 1.129 & 1.557 & 38 & N.S. \\
\hline
\end{tabular}

Table (2) indicates that there is no significant difference between the mean scores of the two groups on the overall $E F L$ reading comprehension pre-test, where " $t$ " value is (1.557), which is not significant at (0.01) level of significance. This means that the two groups are equivalent in their EFL reading comprehension skills.

Table (3): " $t$ " test between the control group and the experimental group in the pre-test of the overall EFL reading speed skills

\begin{tabular}{|c|c|c|c|c|c|c|c|}
\hline Test & Group & N & Mean & S.D & T-Value & D.F & Sig. \\
\hline $\begin{array}{c}\text { EFL Reading Speed } \\
\text { Skills }\end{array}$ & Cont. & r. & 9.100 & 1.62 & & & \\
\cline { 2 - 5 } & Exp. & r. & 9.300 & 1.75 & 0.375 & 38 & N.S. \\
\hline
\end{tabular}

Table (3) indicates that there is no significant difference between the mean scores of the two groups on the overall $E F L$ reading speed pre-test, where " $t$ " value is (0.375), which is not significant at (0.01) level of significance. This means that the two groups are equivalent in their EFL reading speed skills.

\section{- B. Design}

The present research is a partially mixed research methodology. It combines both quantitative and qualitative modes of inquiry to help bridge the gap between quantitative and qualitative research. According to ElSweedy (2012), the present research is a partially mixed research because both the qualitative phase and quantitative one are included in the overall research to provide unified understanding of the RT instruction, $O R F$, reading comprehension and reading speed skills. Therefore, to conduct the quantitative analysis, the pre-post control group design was used. The researcher used two groups: an experimental group and a control group. Both groups were tested before and after conducting the experiment. This design is used when the researchers want to study cause and effect relationships between two or more variables through the active manipulation of the independent variable

\section{0}


and through assigning randomly subjects into two equivalent groups: the control group and the experimental group.

\section{- C. Instruments}

In order to fulfill the purposes of the study, the following instruments were designed.

\section{- A .EFL Oral Reading Fluency Skills Test (ORFT)}

The EFL Oral Reading Fluency test was prepared by the researcher to measure ORF skills among second year preparatory school pupils. It was used as a pre-post test. The test consisted of two reading passages suitable for pupils' level and background knowledge. There are two student passages and two teacher passages. Each teacher passage has a code identifying the passage which should match the one on the student passage in this research, The researcher prepared an unnumbered copy of the passage (student copy) and a numbered copy of the passage (examiner copy). Numbering the passage in the examiner's copy makes it easy to count the total words read. The passage was followed by spaces to be filled by the researcher concerning; the number of total words read during a one minute time period; the number of errors; the number of words read correctly (reading rate) and the number of words read correctly divided by the total word read multiplied by 100 (accuracy).

After administering the ORF test, the researcher and another EFL instructor graded the pupils' ORF in the preposttest and the mean was calculated. They have the same experience and qualifications. They used the coding system (Zutell \& Rasinski (1991)'s Multidimensional Fluency Scale for Reading prosody, (See Appendix 1) to measure ORF subskills. This scale consisted of four dimensions; expression and volume, phrasing, smoothness and pace. Each of these dimensions consisted of a 4-point rating system. To calculate the pupils' oral reading rate, the researcher counted the number of total words read in one minute, then counted the errors and applied the following formula:

- Total words read- errors = words read correctly per minute (WCPM)

\section{1}


To estimate oral reading accuracy, the researcher divided words read correctly in a minute by the number of total words read multiplied the 100 and used the following formula:

- Words read correctly $\div$ total words read $\times 100=\ldots \%$ oral reading accuracy

Two research assistants, each a preservice teacher with 12 hours of coursework in reading education, were trained by the researcher to score the fluency of the oral readings. (See Appendix 2)

\section{- B.EFL Reading Comprehension Skills Test}

The EFL Reading Comprehension test was prepared by the researcher to measure reading comprehension skills among second year preparatory school pupils. It was used as a pre-post test. It consisted of two reading passages suitable for pupils' level and each passage was followed by ten multiple choice questions. Each question is followed by four choices. To determine the time of the reading comprehension test, the researcher recorded the time of the 20 pupils who answered the test during the piloting administration. In order to measure the time of the test, it was calculated by getting the mean of the fastest pupil score and the slowest pupil score as follows: (See Appendix 3)

- Test Time $=$ the fastest pupil score + the slowest pupil score $\div 2$

- Test Time $=25+35 \div 2=30$ minutes.

\section{- C.EFL Reading Speed Skills Test}

The EFL Reading Speed Test was used to measure reading speed skills among second year preparatory school pupils. The reading speed skills adopted from Alarfaj \& Alshumaimeri (2012)'s list of EFL reading speed skills (See Appendix 4). The test was used as a pre-posttest. It consisted of one reading passage. Reading speed was measured by giving the student a passage of text, written on grade level, that has not been read by him or her prior to this assessment (Rinehart, 1999). First, the teacher chose a passage at the individual's reading level, and asked the student to read the passage orally. The pupil was timed for one minute and read out loud as much of the passage as he

\section{2}


or she could in that time. Then, the researcher marked any errors that pupil made on another copy of the passage, and stopped the pupil at the end of one minute. The teacher counted up the number of words read correctly to determine each pupil's reading fluency, recorded in WCPM. In the end, the researcher calculated the number of words correctly pronounced and identified the reading speed. This was done by taking the total number of words that were read correctly and dividing them by the number of words in the passage. It confirmed that reading speed and accuracy were measured by the number of correct words per minute (CWPM) read from the narrative passages by each student. Measures of CWPM taken as pre and posttests could be used to plot student's oral reading fluency progress. (See Appendix 5).

\section{- D.EFL Reading Speed Observation Checklist}

EFL Reading Speed Observation Checklist was prepared by the researcher to assess reading speed skills among second year preparatory school pupils. It was used for formative (ongoing) assessment to monitor students' behavior and progress towards reaching stated goals. It indicated if a student accomplished the listed reading speed skills or not. Nothing was included about the quality of performance. It was used in pre and post administration when pupils perform the reading speed test. It was used in pre administration to determine the entry level of the subjects of both groups in reading speed. In addition, it was used in post administration to determine the effect of using Readers' threatre - Based Instruction. It consisted of six dimensions; each dimension had three items ranging from "3" marks to "1" mark (1 = Some of the time, 2 = Most of the time ,3 = All of the time).(See Appendix 6)

\section{- E.Semi-Structured Interview}

The interview was constructed to examine the importance of Readers' Theatre -based Instruction among second year preparatory school pupils and its effect on improving EFL oral reading fluency, reading comprehension and reading speed skills. The interview took the format of face to face semi-structured interview. The researcher interviewed pupils

\section{3}


once at the beginning of the study, once in the middle, and once at the end of the study, to gain greater insight on their fluency development, throughout the eight weeks. The researcher generally asked the pupils about their participation in the program. She used open ended questions to avoid responding with yes-no (See Appendix 7). Five pupils participated in the interview and their responses were video recorded. The interview lasted for one hour. At the beginning of the interview, the researcher greeted the pupils and asked them to give brief self-introduction as a way to set the goal for the interview. Then, she told them the purpose of the interview and their own roles. If pupils did not understand any question, she could simplify it or change it .At the end of the interview, the researcher thanked the pupils for their participation.

\section{- Determining the Validity of the Research Instruments}

The EFL ORFT, reading comprehension test, reading speed test, observation checklist and semi-structured interview were submitted to jury members (see appendix 8), they were asked to determine the validity of the instruments in terms of clarity of instructions, items and the passages' suitability for the pupils' level, the coding system and the Multidimensional Fluency Scale for Reading Prosody. They indicated that the tests' instructions were clear and the passages were suitable for pupils' levels and background knowledge, the coding system and the Multidimensional Fluency Scale for Reading Prosody. Therefore, the tests, the observation checklist and the semi-structured interview were a valid measure of $O R F$, reading comprehension and reading speed skills (Face Validity).To ensure the content validity of the tests, they were developed in the light of a systematic and accurate of literature and previous studies. This accurate and systematic review determined the general form of the tests, their form of questions and how they should be corrected. Therefore, the content of the tests was representative of the skills that were intended to be measure. Thus, the tests were valid and having a content validity.

\section{4}


- Determining the Reliability of the Research Instruments The reliability of the instruments was measured by using the test-retest method. The instruments were administered to a group of second year preparatory school pupils at Tukh preparatory school for girls. Then, they were administered to the same group again after two weeks. The Pearson correlation between the two administrations was (0.88) at the 0.01 level. Therefore, the instruments were reliable.

\section{- The Program based on Readers' Theatre-Based Instruction \\ For achieving the purpose of the research, the researcher} designed a program based on Reader's Theatre Instruction. After assessing second year preparatory school pupils' $O R F$, reading comprehension and reading speed skills, the experimental group pupils were required to attend the instruction of RT (See Appendix 9).

- Objectives of the Program based on Readers' Theatre Based Instruction

The program aimed at improving EFL oral reading fluency, reading comprehension and reading speed skills among second year preparatory school pupils.

\section{- Content of the Readers Theatre Based Instruction}

The reading passages chosen for the program were selected from books enriched with topics and scripts that motivate the pupils. These books contained pictures and stories designed for readers' theatre and suitable for the second year preparatory school pupils' levels such as Fredericks (2007a), Fredericks (2007b) and Fredericks (2009).

\section{- Readers Theatre Based Instruction Framework}

The treatment began on 20th October 2013 and continued through 15th December 2013. Pupils met in their regular reading classroom for 50 minutes per day four days a week for 8 weeks. Week 1 was used for pre-testing and week 8 was used for post testing. Each session was devoted to the following: script distribution to students and a minilesson, reading aloud, choral reading and repeated reading, rehearsal, and finally the performance. During the instructional procedures, different sessions had different learning goals and different methods were applied.

\section{5}


The program was taught to the both groups (the experimental and the control group) by the researcher herself. It lasted for eight weeks with twenty four instructional sessions and each session lasted for fifty minutes. At the beginning of the program, the researcher introduced to the pupils what they are going to do. First, she told them about the objectives of the program and what they are supposed to gain as a result of their participation in the program (Goal Setting). After that she told them about the importance of reading in general then oral reading fluency, reading comprehension and reading speed skills. Then she began to introduce the concept of readers' theatre and its importance for language learning and EFL oral reading fluency, reading comprehension and reading speed skills.

Following the introduction of the program, the rest of the program were instructional sessions through which the EFL oral reading fluency, reading comprehension and reading speed skills were introduced. At the beginning of each session, the researcher told students the objectives of the session, the researcher's role, the student's role, the instructional materials that will be used, the activities they will perform and ways of evaluating their progress. At the end of the each session, the researcher gave students some activities related to what they had learned in order to be sure that they mastered the skills in each session (formative evaluation). At the end of the program, the researcher assessed the students' achievement after implementing the program using the EFL oral reading fluency, reading comprehension and reading speed tests (summative evaluation).

\section{- Findings of the Study}

- A.Findings of the Ouantitative Analvsis

The findings of the present research are presented in the light of the hypotheses of the research using the Statistical Package for Social Sciences (SPSS). The findings are stated as follows:

\section{6}




\section{- Findings of Hypothesis (1)}

The first hypothesis states "there is a statistically significant difference between the mean scores of the experimental group and that of the control group in the post test of EFL overall oral reading fluency skills in favor of the experimental group". Table (4) presents the students' mean scores, standard deviations, $t$-value and level of significance of the pre and post assessment of the control group and the experimental group in EFL oral reading fluency skills

Table (4):" $t$ " test between the control group and the experimental group in the post-test of the EFL overall oral reading fluency skills

\begin{tabular}{|c|c|c|c|c|c|c|c|}
\hline Skill & Group & N & Mean & S.D & T-Value & D.F & Sig. \\
\hline Oral Reading & Cont. & r. & 113.80 & 9.356 & 54.729 & 38 & \multirow{2}{*}{0.01} \\
\cline { 2 - 7 } Fluency Skills & Exp. & r. & 289.40 & 10.879 & & \\
\hline
\end{tabular}

Table (4) shows that the experimental group outperformed the control group in the overall oral reading fluency skills, where "t-value" is (54.729) which is significant at the (0.01) level.Thus, the first hypothesis was supported.

\section{- Findings of Hypothesis (2)}

The second hypothesis states "there is a statistically significant difference between the mean scores of the experimental group and that of the control group in the post test of EFL oral reading fluency sub-skills in favor of the experimental group". Table (5) presents the students' mean scores, standard deviations, $t$-value and level of significance of the pre and post assessment of the control group and the experimental group in EFL oral reading fluency sub-skills.

The second hypothesis has the following sub-hypotheses

- There is a statistically significant difference between the mean scores of the experimental group and that of the control group in the post test of EFL oral reading accuracy skills in favor of the experimental group.

- There is a statistically significant difference between the mean scores of the experimental group and that of the control group in the post test of EFL reading rate skills in favor of the experimental group.

\section{7}


- There is a statistically significant difference between the mean scores of the experimental group and that of the control group in the post test of EFL prosody skills in favor of the experimental group.

Table (5): " $t$ " test between the control group and the experimental group in the post-test of the EFL oral reading fluency sub-skills

\begin{tabular}{|c|c|c|c|c|c|c|c|}
\hline Skills & Group & $\mathbf{N}$ & Mean & S.D & T-Value & D.F & Sig. \\
\hline \multirow{2}{*}{$\begin{array}{c}\text { EFL oral reading } \\
\text { accuracy }\end{array}$} & Cont. & $r \cdot$ & 34.050 & 3.347 & \multirow{2}{*}{41.146} & \multirow{2}{*}{38} & \multirow{2}{*}{0.01} \\
\hline & Exp. & $r$ r. & 90.050 & 5.083 & & & \\
\hline \multirow{2}{*}{ EFL reading rate skills } & Cont. & 20 & 71.850 & 9.045 & \multirow{2}{*}{39.154} & \multirow{2}{*}{38} & \multirow{2}{*}{0.01} \\
\hline & Exp. & r. & 184.70 & 9.183 & & & \\
\hline \multirow{2}{*}{ EFL prosody skills } & Cont. & $r$. & 7.900 & 1.0208 & \multirow{2}{*}{18.186} & \multirow{2}{*}{38} & \multirow{2}{*}{0.01} \\
\hline & Exp. & r. & 14.650 & 1.309 & & & \\
\hline
\end{tabular}

Thus, table (5) indicated that the experimental group was much better than their counterparts in EFL oral reading fluency sub-skills where " $t$ " value is (41.146) for EFL oral reading accuracy, (39.154) for EFL reading rate, and (18.186) for EFL prosody skill, which is significant at the level of significance. Therefore, the second hypothesis was confirmed.

In addition, reader's threatre gave pupils the ability to read aloud, pupils' prosody skills improved because they applied the prosodic features in their reading such as stress (emphasis), intonation (pitch), punctuation, expression and phrasing (timing). They observed the use of commas, periods and other punctuation clues. They read with good expression. They also varied the expression and volume to match their interpretation of the passage. They also phrased in clauses and sentence units well and read smoothly with some breaks to correct themselves quickly. They used pauses appropriately within and between sentences and knew when to pause and when not to pause. They grouped words into longer, meaningful units or phrases they read with appropriate pace. Thus, their oral reading fluency improved. These results were consistent with Chen (2006), Keehn \& Shoho's (2008), Sovitsky's (2009), Ward's (2009) and Tsou's (2011) These studies confirmed the effectiveness of readers' theatre in improving oral reading fluency.

\section{8}




\section{- Findings of Hypothesis (3)}

The third hypothesis states "there is a statistically significant difference between the mean scores of the experimental group and that of the control group in the post test of EFL overall reading comprehension skills in favor of the experimental group". Table (6) presents the students' mean scores, standard deviations, $t$-value and level of significance of the pre and post test of the control group and the experimental group in EFL reading comprehension skills

Table (6): " $t$ " test between the control group and the experimental group in the post- test of the EFL overall reading comprehension skills

\begin{tabular}{|c|c|c|c|c|c|c|c|}
\hline Skill & Group & $\mathbf{N}$ & Mean & S.D & T-Value & D.F & Sig. \\
\hline $\begin{array}{c}\text { Reading } \\
\text { Comprehension } \\
\text { Skills }\end{array}$ & Cont. & r. & 5.250 & 1.0699 & & & \\
\cline { 2 - 5 } & Exp. & r. & 15.650 & 2.0590 & 20.044 & 38 & 0.01 \\
\hline
\end{tabular}

Table (6) indicated that the experimental group surpassed the control group in the overall reading comprehension skills where "t-value" is (20.044) which is significant at the (0.01) level of significance. Thus, the third hypothesis was supported.

\section{- Findings of Hypothesis (4)}

The fourth hypothesis states "there is a statistically significant difference between the mean scores of the experimental group and that of the control group in the post test of EFL reading comprehension sub-skills in favor of the experimental group". Table (7) presents the students' mean scores, standard deviations, $t$-value and level of significance of the pre and post test of the control group and the experimental group in EFL reading comprehension subskills.

The fourth hypothesis has the following sub-hypotheses

- There is a statistically significant difference between the mean scores of the experimental group and that of the control group in the post test of EFL identifying the main idea in favor of the experimental group.

- There is a statistically significant difference between the mean scores of the experimental group and that of the

\section{9}


control group in the post test of EFL guessing meaning in favor of the experimental group.

- There is a statistically significant difference between the mean scores of the experimental group and that of the control group in the post test of EFL making inferences in favor of the experimental group.

- There is a statistically significant difference between the mean scores of the experimental group and that of the control group in the post test of EFL asking about details in favor of the experimental group.

Table (7): " $t$ " test between the control group and the experimental group in the post- test of the EFL reading comprehension sub-skills

\begin{tabular}{|c|c|c|c|c|c|c|c|}
\hline Skills & Group & $\mathbf{N}$ & Mean & S.D & T-Value & D.F & Sig. \\
\hline \multirow{2}{*}{$\begin{array}{l}\text { Identifying the } \\
\text { main idea }\end{array}$} & Cont. & r. & 0.850 & 0.489 & \multirow{2}{*}{7.217} & \multirow{2}{*}{38} & \multirow{2}{*}{0.01} \\
\hline & Exp. & r. & 2.250 & 0.716 & & & \\
\hline \multirow{2}{*}{$\begin{array}{l}\text { Guessing the } \\
\text { meaning }\end{array}$} & Cont. & 20 & 1.650 & 0.587 & \multirow{2}{*}{8.255} & \multirow{2}{*}{38} & \multirow{2}{*}{0.01} \\
\hline & Exp. & r. & 3.950 & 1.099 & & & \\
\hline \multirow{2}{*}{ Making inference } & Cont. & r. & 0.900 & 0.641 & \multirow{2}{*}{15.599} & \multirow{2}{*}{38} & \multirow{2}{*}{0.01} \\
\hline & Exp. & T. & 5.250 & 1.0699 & & & \\
\hline $\begin{array}{l}\text { Asking about } \\
\text { details }\end{array}$ & $\begin{array}{l}\text { Cont. } \\
\text { Exp. }\end{array}$ & $\begin{array}{l}r . \\
r .\end{array}$ & $\begin{array}{l}1.800 \\
6.100\end{array}$ & $\begin{array}{l}0.768 \\
0.912\end{array}$ & 16.132 & 38 & 0.01 \\
\hline
\end{tabular}

Thus, table (7) indicated that the experimental group improved their Reading comprehension sub-skills considerably where " $t$ " value is (7.217) for EFL identifying the main idea,( 8.255) for EFL guessing the meaning, (15.599) and (16.132) for making inference, which is significant at the 0.01 level. Therefore, fourth hypothesis was confirmed.

These improvements related to the use of the program, as the program contained various activities and tasks that help pupils to read with understanding. Through participating in the reader's theatre instruction, they become able to determine the main idea of the passage they read. They also guessed the meaning of any word if they did not know the meaning. They performed that through the activities and tasks included in the program. Also, the program improved pupils' ability to make inference based on the information mentioned in the passage. Therefore, their reading comprehension skills improved. Thus, Pupils become excited and enthusiastic about reading when they are presented with the opportunity to participate in Readers'

\section{0}

Journal of Arabic Studies in Fducation \& Psychology (ASEP) 
Theatre.These results were consistent with Sailer's (2006), Caudill-Hansen (2009) and Visser's (2013) that clarified the effectiveness of readers' theatre in improving reading comprehension skills.

\section{- Findings of Hypothesis (5)}

The fifth hypothesis states "there is a statistically significant difference between the mean scores of the experimental group and that of the control group in the post test of EFL overall reading speed skills in favor of the experimental group". Table (8) presents the students' mean scores, standard deviations, $t$-value and level of significance of the pre and post assessment of the control group and the experimental group in EFL reading speed skills

Table (8): " $t$ " test between the control group and the experimental group in the post- test of the EFL overall reading speed skills

\begin{tabular}{|c|c|c|c|c|c|c|c|}
\hline Skill & Group & N & Mean & S.D & T-Value & D.F & Sig. \\
\hline $\begin{array}{c}\text { Reading Speed } \\
\text { Skills }\end{array}$ & Cont. & r. & 8.750 & 1.069 & 16.066 & 38 & 0.01 \\
\cline { 2 - 6 } & Exp. & 20 & 15.150 & 1.424 & & & \\
\hline
\end{tabular}

As shown in table (8), there is a statistically significant difference between the mean scores of the experimental group and that of the control group in the post test of EFL overall reading speed skills in favor of the experimental group, where "t-value" is (16.066) which is significant at the (0.01) level of significance. Thus, the fifth hypothesis was supported.

\section{- Findings of Hvpothesis (6)}

The sixth hypothesis states "there is a statistically significant difference between the mean scores of the experimental group and that of the control group in the post test of EFL reading speed sub-skills in favor of the experimental group". Table (9) presents the students' mean scores, standard deviations, $t$-value and level of significance of the pre and post test of the control group and the experimental group in EFL reading speed sub-skills.

The sixth hypothesis has the following sub-hypotheses

- There is a statistically significant difference between the mean scores of the experimental group and that of the

\section{1}

Journal of Arabic Studies in Education \& Psychology (ASEP) 
control group in the post test of EFL picking written symbols in favor of the experimental group.

- There is a statistically significant difference between the mean scores of the experimental group and that of the control group in the post test of EFL Expanding the reading vision of the eyes in favor of the experimental group.

- There is a statistically significant difference between the mean scores of the experimental group and that of the control group in the post test of EFL enhancing the focus on reading in favor of the experimental group.

- There is a statistically significant difference between the mean scores of the experimental group and that of the control group in the post test of EFL flexible Eyes movements and stopping the backward movement of the eyes (regression) in favor of the experimental group.

- There is a statistically significant difference between the mean scores of the experimental group and that of the control group in the post test of EFL reducing the number and duration of pauses in favor of the experimental.

- There is a statistically significant difference between the mean scores of the experimental group and that of the control group in the post test of EFL varying speed in favor of the experimental group.

Thus, table (9) indicated that experimental group achieved substantial gain in reading speed sub-skills in comparison to the control group, where " $t$ " value is (7.233) for EFL picking written symbols, (6.242) for EFL expanding the reading vision of the eyes, (5.403) for EFL enhancing the focus on reading, (6.243) for EFL flexible Eyes movements and stopping the backward movement of the eyes (regression), (5.971) for EFL reducing the number and duration of pauses and (5.724) for EFL varying speed, which is significant at the 0.01 level of significance. Therefore, the sixth hypothesis was confirmed.

It was noticed that, pupils repeated the readers' theatre script more than one time, their reading speed increased. Pupils were instructed in how to pick written symbols from the reading passage, expand reading vision of the eyes,

\section{2}

Journal of Arabic Studies in Education \& Psychology (ASEP) 
enhance focus on reading, do flexible eye movement and reduce pauses and vary speed through reading the scripts and participating in the readers' theatre activities that helped them to increase their reading speed. Thus, their reading speed skills improved.

Table (9): " $t$ " test between the control group and the experimental group in the post-test of the EFL reading speed sub-skills

\begin{tabular}{|c|c|c|c|c|c|c|c|}
\hline Skills & Group & $\mathbf{N}$ & Mean & S.D & $\begin{array}{c}\text { T- } \\
\text { Value }\end{array}$ & D.F & Sig. \\
\hline \multirow{2}{*}{$\begin{array}{l}\text { EFL picking written } \\
\text { symbols }\end{array}$} & Cont. & $r$. & 1.400 & 0.598 & \multirow{2}{*}{7.233} & \multirow{2}{*}{38} & 0.0 \\
\hline & Exp. & $r \cdot$ & 2.650 & 0.489 & & & 1 \\
\hline \multirow{2}{*}{$\begin{array}{l}\text { EFL Expanding the } \\
\text { reading vision of the } \\
\text { eyes }\end{array}$} & Cont. & 20 & 1.500 & 0.607 & \multirow{2}{*}{6.242} & \multirow{2}{*}{38} & \multirow{2}{*}{$\begin{array}{c}0.0 \\
1\end{array}$} \\
\hline & Exp. & r. & 2.600 & 0.503 & & & \\
\hline \multirow{2}{*}{$\begin{array}{l}\text { EFL enhancing the } \\
\text { focus on reading }\end{array}$} & Cont. & $r$. & 1.600 & 0.598 & \multirow{2}{*}{5.403} & \multirow{2}{*}{38} & 0.0 \\
\hline & Exp. & T. & 2.550 & 0.510 & & & 1 \\
\hline \multirow{2}{*}{$\begin{array}{l}\text { EFL flexible Eyes } \\
\text { movements and } \\
\text { stopping the backward } \\
\text { movement of the eyes } \\
\text { (regression) }\end{array}$} & Cont. & 20 & 1.300 & 0.470 & \multirow[b]{2}{*}{6.243} & \multirow[b]{2}{*}{38} & \multirow[b]{2}{*}{$\begin{array}{c}0.0 \\
1\end{array}$} \\
\hline & Exp. & $r$. & 2.350 & 0.587 & & & \\
\hline \multirow{2}{*}{$\begin{array}{c}\text { EFL reducing the } \\
\text { number and duration } \\
\text { of pauses }\end{array}$} & Cont. & $r \cdot$ & 1.550 & 0.605 & \multirow[b]{2}{*}{5.971} & \multirow[b]{2}{*}{38} & \multirow[b]{2}{*}{$\begin{array}{c}0.0 \\
1\end{array}$} \\
\hline & Exp. & 20 & 2.600 & 0.503 & & & \\
\hline \multirow{2}{*}{ EFL varying speed } & Cont. & r. & 1.400 & 0.503 & \multirow{2}{*}{5.724} & \multirow{2}{*}{38} & 0.0 \\
\hline & Exp. & $r \cdot$ & 2.400 & 0.598 & & & \\
\hline
\end{tabular}

- B.Findings of the Qualitative Analysis

At the beginning of the program, the pupils read slowly and their reading was full of mistakes, no meaning and boring. After participating in the Reader's Theatre-Based Instruction, they found that practicing Reader's Theatre presentation was purposeful and enjoyable. In the interview data, three pupils had similar positive reaction towards $R T$. They felt that their oral reading ability in English developed because they became more confident and were able to guess what the content of the story was. The researcher interviewed five pupils in Reader's Theater group with questions based on the procedures of the Readers' Theater instruction. Pupils were asked about the various aspects of the Reader's Theater instruction, including reading aloud, rehearsals, performances, group work and their perceptions of the progress made in reading after the instruction.

\section{3}

Journal of Arabic Studies in Fducation \& Psychology (ASEP) 
To understand how pupils perceived the teacher's reading aloud of the texts to model the fluent reading of scripts, some interview questions were asked. An excerpt from the researcher's transcripts provided insight into the pupils' perception about the reading aloud activities in Reader's Theater instruction.

Pupil (1): Teacher's "voice changes" with facial expression in reading aloud to us. It's funny. I like to imitate her. When teacher read the lines 'Oh she is wonderful!

In this excerpt, pupil (1) talked about her experience during the activity of teacher's reading aloud. She liked the way the teacher read the scripts aloud because it was a pleasant experience. She noticed the teacher showed them how to read with proper facial expressions and the proper intonation, and she liked to read in that manner to present the script, as well.

Rehearsal was the period of time that pupils practiced scripts repeatedly with their group members. An excerpt from the transcripts below shows how pupils felt about the repeated reading practice with other group members.

Pupil (2): It is good to have opportunities to review words and sentences in classes.

Pupil (3): Some words were hard for me at the beginning. However, I can read after other group members helped me or from teacher's instruction.

In these excerpts, two pupils expressed their perceptions about a procedure of Reader's Theater instruction, rehearsal. Pupil (2) pointed out one of the important things achieved during rehearsal was repeated reading. Through repeated reading, students were offered opportunities to review new vocabulary words or sentence patterns. She believed that, it was more effective than "rushing to learn new things". Pupil (3) liked rehearsal for the reason that practicing with others would help her when she had problems with reading.

\section{4}


Before, implementing the program some pupils were afraid of stepping out in front of others, even with partners. They felt nervous reading on stage. Then, the researcher clarified the term performance to them. Performance is the show time for pupils to present their efforts after repeated reading practice in rehearsal. The following excerpts are an example to show how pupils perceived the activity of performance during the implementation of Reader's Theater instruction.

Pupil (4): If now I have to read in front of class, I don't feel so afraid now.

T: Why?

Pupil (4): because we have partners.

In the previous excerpt, pupil (4) expressed the difference in her feelings about reading in front of an audience before and after the instruction. She felt more comfortable reading in front of other classmates after the instruction.

Reader's Theater is an oral reading instructional method that requires more than two students to present in front of an audience. The following excerpt presents the pupil's perceptions about his experiences working with others.

Pupil (5): I feel secure because my group leader can help me and I can ask how to read when I don't know how.

In interviews, pupil (1) said, "I didn't know English well before, but I have become much better after joining $R T^{\prime \prime}$. Also, he mentioned, "I am able to guess what the characters talk about now". Pupil 2 said, "I know how to read it by repeated reading." Pupil 3 stated, "Through reviewing, I feel that my oral reading is better than before". These responses indicated that the participants had developed their English reading as well as their reading comprehension to some extent.

Qualitatively, the researcher observed changes in the performance of the Reader's Theater group (five pupils from the experimental group). The notes collected during the study reflected a shift from a passive attitude to one of

\section{5}

Journal of Arabic Studies in Education \& Psychology (ASEP) 
eagerness from the pupils who participated in the Reader's Theater performances. On day one, the researcher announced that we were going to do Reader's Theater, and the pupils just stared at her and said nothing. After the first week of practice and performance, the Reader's Theater pupils' thoughts began to change. Some of the comments from the five pupils were:

Pupil1: "I like it!," "It's fun to do that,"

Pupil 2 :"I like it because they laughed at my part," "They clapped for me!,"

Pupil 3: "I like to do plays!," "When are we going to get another play?"

Pupil 4: It is more interesting, I like it.

Pupil 5: It is so motivating. It is different from what we performed at the classroom.

Consequently, Chen (2006) indicated that the results of the interviews led to a greater understanding of pupils' perceptions of Readers' Theater instruction. Most pupils had positive things to say about Readers' Theater instruction, in terms of reading aloud, rehearsal, performance, group work, and progress made in reading. They appreciated teacher's reading aloud of the texts to model fluent reading. Some pupils liked being offered opportunities to practice the vocabulary and sentences learned during rehearsals. Many pupils also indicated that they liked to practice together. For the performance aspect of the Reader's Theater, some pupils found reading with others helpful, while others were still afraid of reading in front of an audience.

Therefore, these results are consistent with Rasinski (2003) where he clarified that $R T$ is an authentic, entertaining and educationally powerful way to read and communicate meaning. It yields improvements in word recognition, fluency and comprehension. The pupils learned how to decode automatically and read at appropriate rate with proper phrasing, expression and volume by repeatedly reading to perform. Readers' Theatre improves the ability to

\section{6}


read connected text rapidly, smoothly, effortlessly, and automatically. Also, $R T$ is an instructional practice that develops fluency and promotes overall reading growth while increasing self-confidence.

\section{- Discussion of the Results}

The primary purpose of this study was to improve EFL oral reading fluency, reading comprehension and reading speed skills among second year preparatory school pupils through using a program based on Reader's Theatre -Based Instruction. The program included variety of tasks and activities for helping students to enhance their EFL oral reading fluency, reading comprehension and reading speed skills. The results of the study revealed that, the program proved to be statistically and educationally significant in enhancing preparatory school pupils' EFL oral reading fluency, reading comprehension and reading speed skills.

ORF supports students to read texts for meaning to understand an author's message, and be able to engage in meaningful talk about texts. However, some students can read accurately and sound fluently when asked to retell what has been read although they may not have understood an author's message at all. It can be said that after participating in reader's theatre instruction, pupils are characterized by the ability to read quickly and accurately that led to better comprehension of the text. Therefore, there is a clear relationship between oral reading fluency, reading comprehension and reading speed.

These results are consistent with Kuhn (2004) who indicates that the correct use of prosody is a reliable indicator of a student's comprehension. Miller and Schwannenflugel (2006) claimed that intonation, in particular, is directly related to comprehension. In addition, the results are consistent with Hudson, Lane, \& Pullen (2005)'s that clarified the relation between ORF and reading comprehension skills. They indicated that each aspect of fluency has a clear connection to text comprehension. Without accurate word reading, the reader will have no access to the author's intended meaning and

\section{7}


inaccurate word reading can lead to misinterpretations of the text.

\section{- Conclusions}

The effectiveness of the reader's theatre -based instruction may be due to the various activities and tasks the researcher presented to the pupils. Much of educators' effort is often focused on teaching students to decode text, but reading fluency includes more than just quick and accurate word recognition. In order to be fluent readers, students must be able to read with proper expression, thus demonstrating their understanding of the text .Reader's theater instruction combines reading practice and performing. Its goal is to enhance students' reading skills and confidence by having them practice reading with a purpose. Readers' Theater gives students a real reason to read aloud. They can benefit greatly from having opportunities to read a text many times because this helps them develop fluency, vocabulary, and comprehension. One way to reread a text while keeping it interesting for students is through Readers' Theater. In a Readers Theater activity, students read stories that have been scripted like a play, and they act out the story together. Students may practice their parts several times before acting the story out in front of the class, which gets them thinking about their characters and the plot in a focused way. Rather than using elaborate props, costumes, or scenery, students can be encouraged to use vocal, facial, and physical expression to engage with the script and their character.

To do reader's theatre appropriately, students need an authentic reason to repeatedly read or rehearse a text. Thus, the most natural reason to practice is performance. If the teacher wants students to engage in repeated readings, have them perform what they are practicing for an audience. With performance as a goal, students now have a natural reason to engage in repeated readings. Readers Theater is a performance genre- it is a type of reading material to be performed. Moreover, because the focus of the practice is to convey a meaningful interpretation of the text to an audience, Readers Theater is also a natural

\section{8}


vehicle for developing reading comprehension. Therefore, Reader's Theater is one of the best and most authentic ways to engage students enthusiastically in repeated reading to build reading fluency and improve overall reading performance (Rasinski, 2003a)

\section{- Recommendations of the Study}

In the light of previous results, the following recommendations could be presented:

- Training teachers of English language on using readers' theatre-based instruction while teaching English to their students in the early educational stages.

- English language teacher should emphasize the development of the students' oral reading fluency, reading comprehension and reading speed skills in the early educational stages to develop them in the following stages.

- Curriculum designers should make use of readers' theatre -based instruction when designing English language courses.

\section{- Suggestions for Further Research} Based on the findings of the present research, the following implications for further research are suggested:-

- Investigating the effect of readers' theatre -based instruction on English language learning among primary school students.

- Clarifying the influence of readers' theatre -based instruction on other language skills such as listening and writing.

- Investigating the effectiveness of readers' theatre based instruction on developing students' attitudes towards studying English and reading awareness.

- Clarifying the effect of using other strategies on developing pupils' EFL oral reading fluency, reading comprehension and reading speed skills.

- $\underline{\text { References }}$

1. Alarfaj, A. and Alshumaimeri, Y. (2012). The effect of a suggested training program on reading speed and comprehension

\section{9}

Journal of Arabic Studies in Fducation \& Psychology (ASEP) 
of Saudi female university students. Procedia - Social and Behavioral Sciences 31, 612-628

2. Callard,K.(2008). Using Reader's Theater to increase third graders' reading fluency, comprehension, and motivation. Unpublished doctoral dissertation, Nova Southeastern University.

3. Carrick, L.U. (2000). The effects of Readers Theatre on fluency and comprehension on fifth grade students in regular classrooms. Unpublished doctoral dissertation, Lehigh University.

4. Caudill-Hansen, K.J. (2009). Readers' Theater as a strategy to increase comprehension and fluency in sixth grade students. Unpublished doctoral dissertation, Walden University.

5. Chen, J. (2006). A Study of Oral Reading Fluency and Motivation for Reading: The Implementation of Readers Theater in an Elementary English Class.Unpublished Master thesis, National Chung Cheng University, Taiwan.

6. Cox, D. , Miller, M. and Berg, H. (2012). Getting my nervousness out: The power of Repeated Oral Reading Performance to develop fluency in bilingual readers. The Journal of Multiculturalism in Education, 8(1), 1-20.

7. Dalton,K. (2013). The effects of implementing a Reader's Theatre intervention in a first grade classroom. Unpublished doctoral dissertation, Eastern Illinois University.

8. Derringer,A. (2013). The effect project read has on the reading fluency and comprehension of third grade students with special needs. Unpublished master thesis, Rowan University.

9. Dixon, O.J. (2007). Content area readers' theater: The effect on fluency and comprehension. Unpublished doctoral dissertation, University of Houston.

10. El-Garawany, M.S.M. (2010). The effects of repeated reading strategies on developing oral reading fluency and reading comprehension among EFL prospective teachers. Unpublished master thesis, Minufiya University, Egypt.

11. El-Sweedy,N.A.A.A. (2012). The effects of a suggested program on developing beliefs and teaching skills related to writing among

\section{0}


EFL prospective teachers. Unpublished doctoral dissertation, Faculty of Education, Benha University, Egypt.

12. Forney,M.(2013). Teaching content material through reader's theater. Unpublished doctoral dissertation, Fielding university.

13. Fredericks,A.D.(2007a). Mother goose readers theatre for beginning readers. London: Teacher Ideas Press.

14. Fredericks,A.D.(2007b). Nonfiction readers theatre for beginning readers. London: Teacher Ideas Press.

15. Fredericks,A.D.(2009). Fairy tales readers theatre. California: A Teacher Ideas Press Book.

16. Helwa, H.S.A.A. (2010a).The effectiveness of using Annotation Strategy in developing some reading comprehension skills among EFL college students. Unpublished Master thesis, Faculty of Education, Benha University, Egypt.

17. Helwa, H.S.A.A. (2010b). Using KWL plus Strategy for developing some reading comprehension skills among EFL freshmen. Journal of Faculty of Education , Benha University. 21(82), 1-38.

18. Hudson, R. F., Lane, H. B., and Pullen, P. C. (2005). Reading fluency assessment and instruction: What, why and how? The Reading Teacher, 58, 702-714.

19. Jagger,T.P. (2008). The effect of Reader's Theatre on fifth graders' reading fluency and comprehension. Unpublished doctoral dissertation, Walden University.

20. Kariuki,P.N. and Rhymer,S.A. (2012). The effects of Readers' Theatre-Based and Tradition-Based Instruction on sixth-grade students' comprehension at a selected middle school. A Paper Presented at the Annual Conference of the Mid-South Educational Research Association, Lexington Kentucky, November 7-9.

21. Keehn, S. (2003). The effect of instruction and practice through Readers Theatre on young readers' oral reading fluency. Reading Research and Instruction, 42(4), 40-61.

22. Keehn, S., Harmon, J. and Shoho, A. (2008).A Study of Readers Theater in eighth grade: Issues of fluency, comprehension, and vocabulary .Reading \& Writing Quarterly,24(4),335-362 . 
23. Kuhn, M. R., and Stahl, S. A. (2003). Fluency: A review of developmental and remedial practices. Journal of Educational Psychology, 95(1), 3-21.

24. Kuhn, M. (2004). Helping students become accurate, expressive readers: Fluency instruction for small groups. The Reading Teacher, 58, 338-344.

25. Macalister, J. (2010). Speed reading courses and their effect on reading authentic texts: A preliminary investigation. Reading in a Foreign Language, 22(1), 104-116.

26. Madden, K.(2009). Learn To speed read. San Francisco, USA: Creative Commons.

27. Martinez, M., Roser, N., and Strecker, S. (1998). "I never thought I could be a star": A Readers Theatre ticket to fluency. The Reading Teacher, 52, 326-334.

28. Mendes, H.M. (2012). Improving oral fluency in English language learners through readers' theatre. Unpublished master thesis, Saint Mary's College of California.

29. Miller, J. and Schwannenflugel, P. (2006). Prosody of syntactically complex sentences in the oral reading of young children. Journal of Educational Psychology, 98, 839-853.

30. Moore, M.(2011). Improving the reading comprehension of second grade struggling reader's through the instructional activity of Readers' Theater. Unpublished master thesis, Caldwell College.

31. Morales, B. (2013). The effects reader's theater has on 3rd and 4th grade English language learners literacy skills and selfesteem in the ESL classroom. Unpublished master thesis, William Paterson University of New Jersey.

32. Morra,J. (2006). The impact of individualized explicit fluency instruction. Unpublished master thesis, Kean University.

33. Morris, W.E.(2011). The effects of readers' theater on reading fluency and attitudes towards reading. Unpublished master thesis, Saint Mary's College of California.

34. National Reading Panel. (2006). Teaching children to read: An evidence-based assessment of the scientific research literature on

\section{2}


reading and its implications for reading instruction.(Retrieved on 6-2013) . (http://www.nichd.nih.gov/publications/nrp/findings).

35. Osborn,D.F. (2007). Developing oral reading fluency: Effects of daily use of word walls and daily independent silent reading on oral reading fluency development of second grade students. Unpublished doctoral dissertation, Liberty University.

36. Owens, C. (2012). Using readers' theater to improve second graders' reading fluency, comprehension, and motivation .Unpublished master thesis, Sierra Nevada College.

37. Rasinski, T. V. (2002). Speed does matter in reading. The Reading Teacher, 54, 146-151.

38. Rasinski, T. V. (2003a). Fluency is fundamental: Fluency is a bridge between two other major components of reading decoding and comprehension. Instructor, 113(4), 16-20.

39. Rasinski, T. V. (2003b). The fluent reader. New York: Scholastic Professional Books (cited in). Cox, D. (2007). Oral reading performance and the synergy of fluency, comprehension, and motivation: a case study of a sixth grade class. Unpublished doctoral dissertation, Texas Tech University, U.S.A.

40. Rasinski, T., Rikli, A., and Johnston, S. (2009). Reading fluency more than automaticity? More than a concern for the primary grades? Literacy Research and Instruction, 48, 350-361.( An online Eric database abstract No. EJ856834).

41. Rasinski,T.(2013). From phonics to fluency: Effective and engaging instruction for two critical areas of the reading curriculum. Paper presented at International Reading Association, San Antonio, TX.

42. Ruskey,N.(2011). Increasing Fluency using Repeated Reading. Unpublished master thesis, University of Wisconsin-Stout.

43. Sailer,J.K.(2006). The effects of reader's theater on 6th grade students' fluency, comprehension, and reading attitude. Unpublished master thesis, Wichita State University.

44. Samuels,S.J. (2006). Reading fluency: Its past, present, and future . In : T, Rasinski, C , Blachowicz and K, Lems (eds). Fluency instruction research-based best practices (7-20). New York :The Guilford Press.

\section{3}


45. Seifeddin ,A.H. (1991).Effects of some teaching activities and techniques on improving oral reading of junior learners. Journal of Educational and Psychological Sciences, Faculty of Education, Minufiya University, 6(2), 1-28.

46. Smith, D.M.(2011). Readers theatre: Its effectiveness in improving reading fluency, student motivation, and attitudes toward reading among second-grade students. Unpublished doctoral dissertation, Pennsylvania State University. U.S.A.

47. Sovitsky,C. (2009). Read it like you mean it: Using readers' theatre to improve oral reading fluency. Unpublished master thesis, University of California, U.S. A.

48. Tankersley, K. (2003). The threads of reading: Strategies for literacy development. Alexandria, Virginia USA: Association for Supervision and Curriculum Development.

49. Tharp, C. (2012). Using Readers' Theater to develop fluency in students with learning disabilities. Unpublished doctoral dissertation, Manchester College.

50. Tsou, $W$. (2011). The application of Readers Theater to FLES (Foreign Language in the Elementary Schools) reading and writing. Foreign Language Annals ,44(4), 727-748.

51. Vaughnm S. and Thompson, S.L.(2004) . Research-Based Methods of reading instruction Gades K-3.Alexandria,Virginia USA: Association for Supervision and Curriculum Development.

52. Visser, T.E. (2013). The effect of reader's theater on the reading comprehension, fluency and motivation of the elementary English language learning student. Unpublished master thesis, Northern Michigan University, U.S.A.

53. Ward, L.(2009). Tales for a fourth grade something: Using readers' theatre to promote reading comprehension. Unpublished master thesis, University of California, Davis. U.S. A.

54. Wolf,M and Katzir-Cohen, T. (2001). Reading fluency and its intervention. Scientific Studies of Reading, 5 (3), 211-239.

\section{潾潘潾潘㴽}

\section{4}

